\title{
Individual earnings and household incomes: mutually reinforcing inequalities?
}

\author{
Wiemer Salverda \\ University of Amsterdam, Amsterdam Institute for Advanced Labour Studies (AIAS) and Amsterdam Centre for \\ Inequality Studies (AMCIS), The Netherlands, and Coordinator of Growing Inequalities' Impacts (GINI) \\ Research Project 2010-2013 (gini-research.org)
}

\begin{abstract}
Inequality's rise and impacts deservedly receive much attention in scientific and public debates, with most of the attention being paid to the very top of the income or wealth distribution. This contribution complements this with a study of the broader top - the top 10 per cent - where labour-market outcomes play a predominant role. However, the analysis still needs to come to terms with the death of the singlebreadwinner model and its replacement with two or more earners in the household. At the same time this brings in the (household distribution of) hours of work as an important new dimension of inequality, in addition to the traditional wage levels. It will be shown, using data for $26 \mathrm{EU}$ countries, that these changes complicate the linkages of wage inequality and income inequality and add to the importance of employee earnings for income inequality. For this analysis, aggregate inequality measures will be put aside in favour of a more detailed consideration across the distributions of earnings and incomes. Some implications for analysis and policy are discussed in the conclusion.
\end{abstract}

Keywords: income inequality, wage inequality, top incomes, breadwinner model, household labour supply

JEL codes: $J 21, J 22, J 31, H 31$

\section{INTRODUCTION}

Income inequality's relentless rise in many countries is a heavily debated issue, with regard to its driving forces as well as its implications for society and the economy. The top-incomes project (Atkinson/Piketty 2007), the OECD $(2008 ; 2011)$, and the GINI research project (Salverda et al. 2014) all find growing inequality in many countries (albeit not all and not always). Most of the attention goes to the very top (the top 1 per cent and smaller fractions): very small numbers with extreme riches, especially since Piketty (2014) has succeeded in adding the distribution of wealth, which is much more uneven than the income distribution, to the public debate. ${ }^{1}$ However important, this tends to keep the massive changes in the labour market, which strongly affect the broader picture of inequality, out of the limelight. Here, drivers and implications of income inequality are found at the same time. In this contribution I aim to shed light on these interconnected mechanisms, which may ultimately be more difficult to change than the position and behaviour at the very top.

I will argue, first, that a satisfactory analysis is rendered difficult by a deep gap between the analyses of the wage distribution of individuals operating in the labour market, on the one hand, and those of the distribution of household incomes on the other hand. One important

1. Maestri et al. (2014) discuss the international comparison of wealth inequality and the relationship between the distributions of wealth and income. 
explanation for this sorry situation is the sea-change brought to the workings of the labour market in recent decades by the strong growth of educational attainment, female employment and part-time jobs, and the concomitant demise of the single breadwinner as the core model of household behaviour on the labour market. However, in much of the data gathering and analysis important remnants, if not more, of this model seem to linger on. A complete overhaul seems essential to enable the two literatures to be integrated. In the main, third section, I attempt to provisionally bridge the gap by considering, first, the importance of labourmarket earnings as a source of household incomes; second, the linkage between the pay and working efforts of the individuals who contribute those earnings to their households; and, third, the way the unequal bundling of individual earnings into household incomes may reinforce labour-market inequality. Finally, I briefly summarise and discuss some analytical and policy implications.

Before starting, a quick digression on the measuring of inequality may be helpful.

$A$ note on measuring inequality Inequality is a complex aggregate outcome across units, be they persons or households. Three issues are relevant here. First, single coefficients or indices at the aggregate level have difficulty telling us where in the distribution things are happening or are happening most strongly - the rising popularity of the topincomes literature is witness to that. ${ }^{2}$ Thomas Piketty (2014: 243) explains this very well: '.. synthetic indices, such as the GINI coefficient, ... mix very different things, such as inequality with respect to labour and capital, so that it is impossible to distinguish clearly among multiple dimensions of inequality and the various mechanisms at work' ${ }^{3}$ In lecturing his students, he advises them to focus on decile and percentile shares - which is also done below. Such shares are of eminent importance for the top and bottom deciles/ percentiles as these have no outer boundaries, contrary to all quantiles in between. Consequently, the often-used ratio of D9:D1 decile cut-offs or boundaries can depict a very different development from the ratio of the 10:1 decile shares (S10:S1). ${ }^{4}$ Second, and in particular, certain categories of income may be shifting over the distribution and this may be observable in daily life, generating feelings of rising inequality among the population that, even if they are dramatic, need not show up in the aggregate measure. The latter may remain stable while important 'tectonics' - upwards for some, downwards for others are working under the surface. Naturally, further detail will need to be added to the quantiles of the distribution, beyond their simple shares, to capture this. My discussion of labour incomes below is a case in point. Third, income concepts matter too. The usual, if not exclusive, focus on equivalised disposable incomes ${ }^{5}$ may hide from view

2. This applies in spite of the fact that Gini coefficients and top-income shares may correlate to some extent (Leigh 2007; Alvaredo 2011).

3. He is in the good company of Jan Pen and Jan Tinbergen (1976, in Dutch): 'We are of the opinion that the distribution of incomes is too complex to be captured by a single indicator, even if it is an advanced measure such as the Theil coefficient ... The Gini coefficient is a very unwieldy measure. ... We do like decile ratios, but we realise very well that they mask extreme inequalities. The top 1.25 per cent share already helps a lot in this respect'.

4. The latter is 1.7 to 2.6 times higher than the former for net-equivalised incomes in 2013 depending on the country (Eurostat [ilc_di01]).

5. Policy-making has a strong focus on equivalised disposable incomes; witness the European poverty measure and the exclusive attention paid to the net-equivalised income distribution by Eurostat. The effects of equivalisation, and the changing household formation behind it, seem strongly underdeveloped in the literature. Compare for the role of household formation, for example Peichl et al. (2010) for the German case; in the case of the Netherlands the middle of the distribution (5-6th decile average) stagnated in real terms on balance between 1977 and 2013 for gross as well as net incomes, but it 
importantly diverging trends in the distribution of primary, gross or disposable incomes, and thereby the effects of markets, redistribution and household formation. Here I start from the distribution of gross incomes - that is, all incomes over which taxes and contributions are paid - but leave open the trajectory of redistribution and equivalisation. Gross incomes are the currency of the top-incomes literature and also provide the starting point of the heated American debate on stagnating median incomes.

\section{TWO TALES: WAGE INEQUALITY AND INCOME INEQUALITY7}

Though it is common knowledge that the earnings from paid labour are by far the most important component of incomes in modern society, and in spite of the fact that the growing inequality of earnings has been receiving a lot of attention, the connection between individual earnings and household incomes, and their respective inequalities, needs much closer scrutiny. Two extensive but largely separate literatures exist: one addresses wage inequality in the labour market and the other income inequality in society, with a gulf between them (Večerník 2010: 2). They differ in focus (individuals versus households; gross earnings versus disposable incomes), analysis (explaining pay from individual characteristics versus relating incomes to household needs), measurement (hourly earnings ${ }^{8}$ versus annual incomes), and measures (percentile ratios versus aggregate coefficients and indices). To bridge this gulf, the analysis of labour-market inequality needs to broaden beyond individual wage rates and incorporate individual employment including annual working hours as well as household membership.

Only a trickle of publications explicitly addresses the gap, some of them very interesting. For example, in the special 2010 issue 'Cross-sectional economic facts for macroeconomists' of the Review of Economic Dynamics seven rich-country teams apply a standardised approach to assemble comparable information about the level and the evolution, over time and over the life cycle, of several dimensions of economic inequality, including wages, labour earnings, income, consumption and wealth. ${ }^{9}$ Unfortunately, important lacunae remain. Other valuable contributions (for example, Gottschalk/Danziger 2005; Atkinson/Brandolini 2006; Kenworthy 2008; OECD 2011) proceed in different ways. Some include those without work, others do not. Most, but not all, account for the distribution of jobs (and hours) separately from earnings. Some equivalise incomes throughout, others add this as a separate, final step. Some focus on employees, others include the self-employed and/or jobless. Very few studies link individuals consistently to their

rose by 18 per cent for net-equivalised incomes. For the nature of equivalisation - which is an arbitrary treatment of the income data - compare, for example, Aaberge/Melby (1998) who study the effects of equivalisation if household economies of scale are made income-dependent.

6. As the argument here concerns gross incomes only, it is certainly not the last word about inequality, which depends also on the redistribution and household equivalisation of incomes. However, redistribution can only grow bigger if it needs to compensate for growing inequality at the gross level.

7. For a more detailed evaluation see Salverda/Checchi (2014: sec. 18.2).

8. In practice, full-time earnings or 'full-time-full-year' earnings are often used, these being the only data gathered - a clear remnant of the single-breadwinner society and implicitly assuming that full-time hours are the same, cross-country or over-time (quod non).

9. Blundell/Etheridge (2010) (UK), Brzozowski et al. (2010) (Canada), Domeij/Floden (2010) (Sweden), Fuchs-Schündeln et al. (2010) (Germany), Heathcote et al. (2010) (USA), Japelli/Pistaferri (2010) (Italy), and Pijoan-Mas/Sánchez-Marcos (2010) (Spain). 
households. The treatment of interrelated males and females is sometimes problematic or the rise of singles is ignored. Thus, a body of stylised approaches and facts has yet to come about, and this contribution aims to take another step in that direction.

The relevance of all this lies in the fact that the world of the single breadwinner (where each household has one full-time main earner and no more than that) has gone. In that world, individual wage inequality and household income inequality were virtually identical. This enabled the labour market to take care of the household to some extent, for example by means of a minimum wage aimed at providing minimum subsistence to a standard type of household. Nowadays, by contrast, workers are scattered very differently over households, witness debates on household joblessness and on (educational) homogamy. For example, in the United Kingdom the employment rates of individuals and of households differed by only 2 percentage points in 1979, but by the year 2000 this had grown to 15 percentage points (Blundell/Etheridge 2010: figs 2.1 and 2.3). Simultaneously, female employment rose formidably, coming close to a doubling of the national labour supply, in addition to Richard Freeman's (2006) famous doubling of the global labour force after 1989. This has happened in conjunction with a strong increase in educational attainment - implying not only very significant changes in labour-market competition but also a much increased share of the working-age population who participate in education instead of employment. The strong demographic shift towards single-person households has further added to the decline of the single-breadwinner family. The exclusive position of full-time workers has given way to a significant rise in part-time jobs. These contribute substantially to earnings inequality: on an annual basis the effect of a possible pay penalty for part-timers is greatly enhanced by the fewer weekly hours worked and the incidence of part-year working. It makes the hours of work an equally important (but not necessarily independent) component to analyse next to the level of pay for both individual wages and household incomes and the connection between the two.

\section{WAGES AND INCOMES}

In three consecutive steps I consider the links between wage inequality and income inequality. The first step underlines the aggregate importance of wage earnings for household incomes and their distribution. Second, I compare the individual inequalities of wages and hours worked directly to those of household incomes. This includes considering the increasing number of wage earners who join each other in households higher up the income distribution. Finally, I discuss how this combination may mutually reinforce the inequalities on both sides when it leads high-income households to compete in low-wage labour markets.

\subsection{Distributive importance of wages}

Wage earnings are the most important source of income in virtually all EU countries. Figure 1 spells out that employee households - defined here as households where wage earnings make the largest contribution to the household's total income - constitute a 56 per cent majority of all households for the average of 26 EU countries. In most countries their share ranges between 50 per cent (Romania) and 66 per cent (Luxembourg), the exceptions being Greece and Italy where they make up only 40 to 45 per cent and the majority apparently have other sources of income. In all countries their shares in 


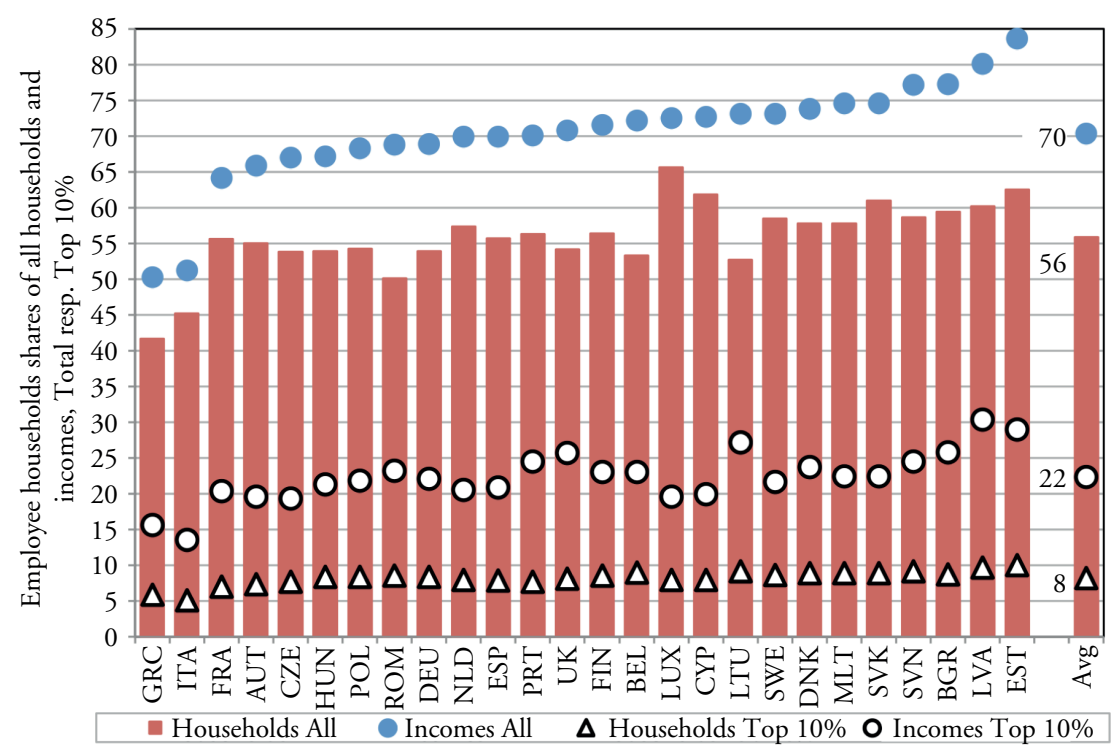

Note: Avg = Average, unweighted.

Source: Calculated from Eurostat, EU-SILC wave 2011 (compare Salverda/Haas 2014).

\section{Figure 1 Employee households among all households and incomes: total and top 10 per cent, 2010}

total income are much higher - note that the graph ranks the countries by these shares -70 per cent as against 56 per cent. Greek and Italian shares are now just over 50 per cent, but they remain outliers compared to the rest that ranges from two-thirds (France, Austria, Czech Republic, Hungary) to 80-85 per cent (Latvia, Estonia).

This implies that employee household incomes are above average, a fact that is mirrored sharply in the top-10-per-cent shares of incomes. Employee households are strongly overrepresented in this share. Employee households with a top-10-per-cent income comprise 8 per cent of all households and receive 22 per cent of all incomes on average as shown in Figure 1. This accounts for 15 per cent of all employee households and 32 per cent of their incomes on the one hand, and amounts to 80 per cent of all top-10-per-cent households and their incomes on the other hand. The remainder of the top shares go to entrepreneurial households and pensioners. At one extreme employee households make up the entire top 10 per cent in Estonia, while in Greece and Italy it is only half. The level of income of those top-10-per-cent employee households is 2.7 times that of the other, bottom 90 per cent, employee households - varying from 2.5 times in Sweden or the Czech Republic to 3.2 times in Portugal or the UK, closely followed by Latvia.

Clearly, employee households play a very important role in income inequality in crosssection, which warrants further scrutiny. Unfortunately, information on the preceding evolution, which may help us understand how this situation was brought about, is scarce. ${ }^{10}$

10. The European databases such as SILC (used in Figure 1) or ECHP are of little help for the longrun evolution. Being based on small samples they are also unsuited to determining small top shares with any precision, calling into question the presentation of top percentiles by Eurostat on its website. 


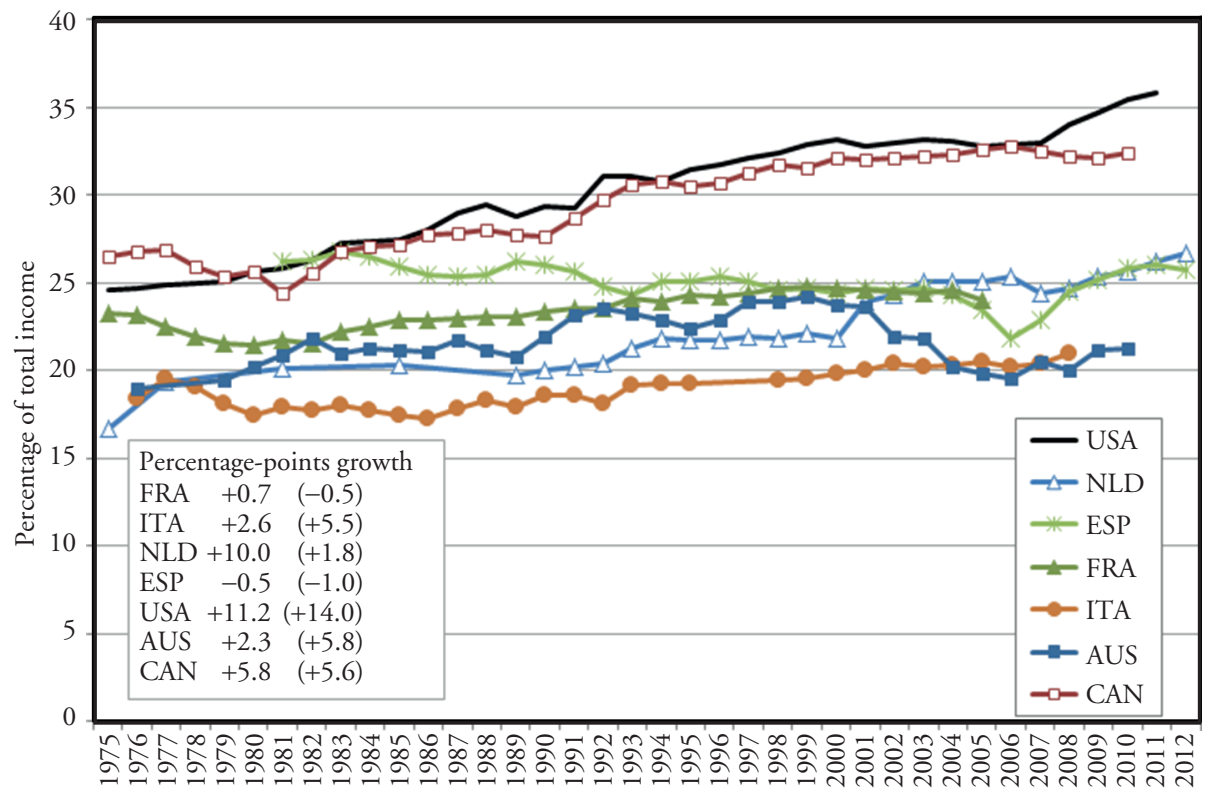

Note: Data concern 'fiscal units', which treat non-partnered earners independently from the households they may be part of.

Source: World Top Incomes Database, extended for the Netherlands beyond 1999 by the author, USA 2011-2013 from January 2015 update (http://eml.berkeley.edu/ -saez/).

Figure 2 Employee household incomes in the top 10 per cent, percentage of total income, 1975-2012

Piketty/Saez (2003) have demonstrated the growing importance of labour incomes for the broad top-10-per-cent of incomes in the USA. Consistent with this, the World Top Incomes Database, maintained at the Paris School of Economics, comprises similar data for a few of the above countries: France, Italy, the Netherlands and Spain (Figure 2). Since 1975 the top share attributed to wage earnings has increased by 11 percentage points in the USA, growing away from - or ahead of - European levels. It is closely followed by Canada since 1980. Dutch growth by 10 percentage points almost matched this, and has brought the country to the top of these European countries. French and Italian growth was considerably less but still positive, while the Spanish level has stagnated. The Australian level fluctuated within the European range. Compared to total top-10-per-cent growth for all sources of income (mentioned between brackets in Figure 2's box), other types of incomes have grown considerably in the USA and Italy (3 percentage points) but have fallen in the other countries (by no less than 8 percentage points in the Netherlands). Because of these substantial differences we have to be careful about drawing general conclusions. Nevertheless, it seems safe to conclude that in many countries, not just the US, wage earnings have been moving up the household income distribution and may now have reached higher levels than ever before (compare, for example, the Review of Economic Dynamics papers already mentioned, or Brewer/ Wren-Lewis 2012: tab. 5). 


\subsection{Combining wages into incomes ${ }^{11}$}

The above indicates an upward shift in incomes from wages but does not tell us how the latter actually combine into the former and contribute to their inequality, including particularly how hours worked and hourly earnings come together in the process. For this we focus on employee households only, pictured according to their own decile distribution of total gross earnings received - on an annual basis for the sake of consistency with the distribution of incomes. For the average of the same 26 EU countries shown in Figure 1 and for the year 2010, household total earnings obviously rise with the deciles, rather linearly up to the eighth decile (5.6 times the bottom decile), somewhat faster in the ninth decile (7.0 times), and then especially fast in the tenth decile (11 times $=$ S10:S1 ratio). This evolution can be broken down into a slow, steady growth over the deciles of hours worked by the household, up to 2.7 times more at the top compared to the bottom, and a rise in average hourly earnings which steepens and takes responsibility for the faster growth of total earnings in the 9th and 10th deciles, generating an S10:S1 ratio of 4.1.

Household total earnings over the deciles can also be broken down by the earnings of the particular individuals averaged within the household. Now hours worked show less variation, for the obvious reason that individuals have to make do with 24 hours in a day. An average individual in a top-decile household works only 1.4 times more hours compared to the bottom decile, while corresponding hourly earnings are 3.7 times higher. The difference is made up by a larger number (2.2) of individuals with earnings in households at the top compared to households at the bottom. Finally, if we look at the individuals ranked by their own earnings regardless of their household membership, we happen to find roughly the same relative level of earnings at the top and a higher relative number of hours (1.9). Evidently, countries differ in the aggregate as well as in their breakdown by hours and pay levels. The international differences in S10:S1 ratios for individual annual hours are small (1.1-1.8) and less than for corresponding hourly earnings (2.3-5.8) if household-ranked; if individually ranked, the international variation in hours is somewhat larger (1.1-2.7), due to the presence of part-time employment, while that for earnings is much larger (5.1-19.1).

This has two important implications. First, a difference in individual annual hours is evened out over households, or, to put it differently, part-time work is found also higher up the income distribution. Second, the combination of earnings in the household mitigates the inequality of individual earnings to the extent that if all working individuals in the top household decile (2.2, varying 1.9-3.0) would be earning top individual earnings (3.7 ratio), the top household's top earnings would amount to 8.1 (varying 4.8-13.1) times the first decile's, whilst the effective outcome would be only half of that (4.1): a 50 per cent reduction. In other words, individual (annual) earnings are not perfectly correlated across households; that is, in dual and multiple-earner households, ${ }^{12}$ neither individual pay levels nor individual hours are. This holds for all countries: there is a consistent reduction in inequality, varying from 37 per cent in Slovakia to 60 per cent in Greece, with about half the countries hovering around the 50 per cent average. We can conclude from this that the joint supply of labour from households reduces the effects of individual wage inequality among the individuals involved due to compensatory developments within households for both hours worked and levels of earnings. At the same time, however, that labour supply, by the very fact that it is joint in the household and raises the

11. For more detail, see Salverda/Haas (2014).

12. Heathcote et al. (2010) show an increase in earnings correlation between married partners from 0.40 to 0.60 (1967-2005), which is still far from perfect. 


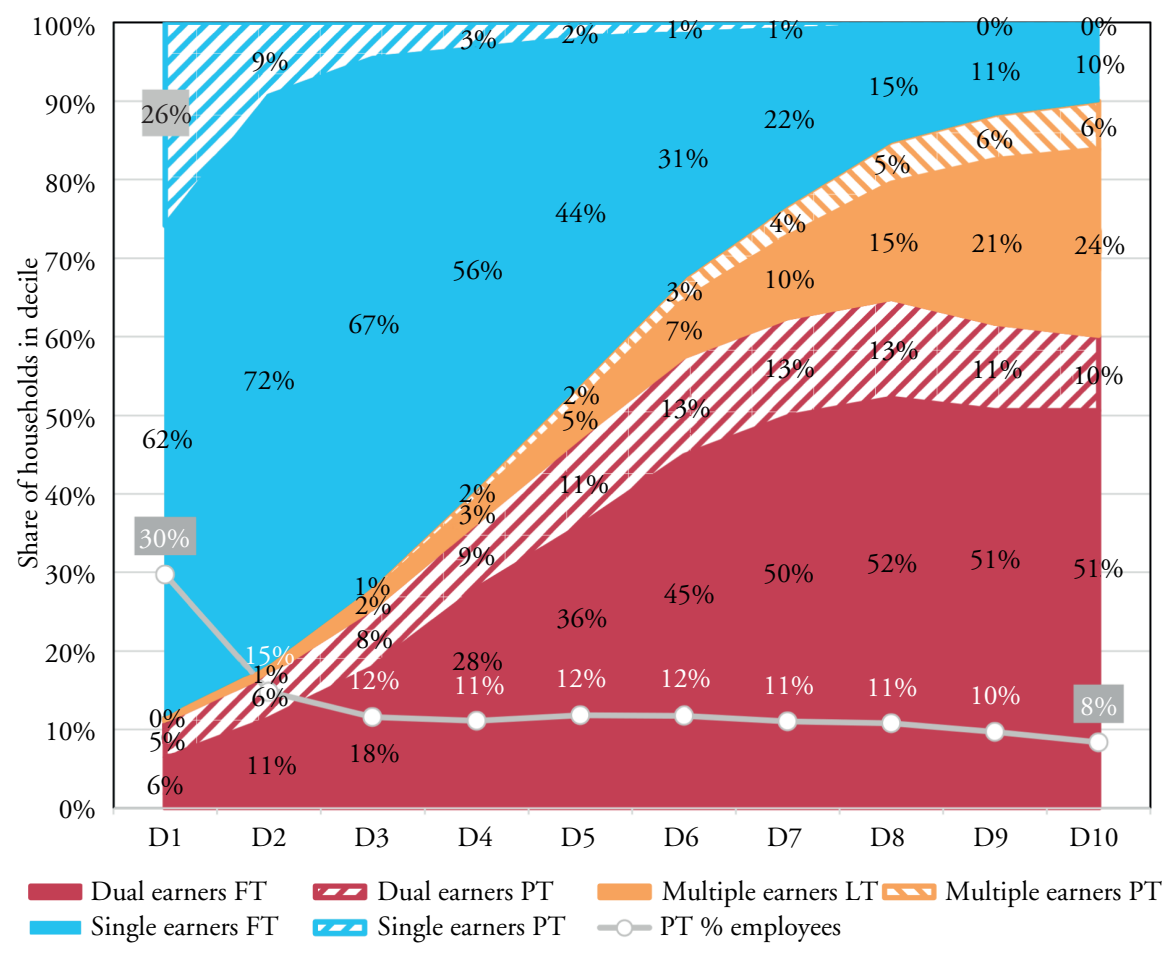

Source: Calculated from Eurostat, EU-SILC wave 2011.

Figure 3 Earners working full- or part-time within labour-household gross-income deciles, 2010

total of hours worked by the household, is an important factor in determining household total earnings and thus incomes. However, in international comparison the effects of hours vary relatively little and therefore wage inequalities are the main driver of diverging household earnings inequalities from that perspective.

The above corroborates the finding that out of the strong Dutch increase in earnings at the top that is shown in Figure 2, more than half is due to the growing contribution of second earners in a household (Salverda/Atkinson 2007: fig. 10.9A, extended to 2012 in Salverda 2014: fig. 2.2). Similarly, employed couples make a large contribution to rising income inequality in the UK (Brewer/Wren-Lewis 2012). ${ }^{13}$ It underlines the relevance for income inequality of the number of earners in a household and the variation in hours worked.

We consider how this evolves over the income distribution of employee households in Figure 3, distinguishing between the number of earners (single, dual or more: multiple) on the one hand and their full-time or part-time working hours on the other hand. Single earners appear largely to concentrate in the lower deciles: comprising close to 90 per cent of all households at the bottom and only 10 per cent at the top. Dual earners make up most of the small remainder at the bottom while at the top they have a

13. Compare Salverda/Checchi 2014: fig. 18.9. 
60 per cent majority and are kept company by multiple-earner households who have a 30 per cent share. Evidently, the distribution of employees is even more skewed towards the top household deciles as persons with income from earnings in dual-earner and multipleearner households are counted individually. As a result, the bottom household earnings decile comprises less than 5 per cent of all individual workers while the top decile contains 3.5 times more. Similarly, only a minority of 30 per cent of all employees are single earners and a large majority of workers operate from a multiple-earner background.

The role of part-time employment is important for all three categories of households, measured here as the presence of at least one worker holding a part-time job. For single earners part-time employment is especially strong at the very bottom, while for dual earners it is significant across all deciles; for multiple-earners its role increases gradually in the higher deciles. In the top decile, roughly one-fifth of dual-earner as well as multiple-earner households have a part-time worker. Unsurprisingly, but striking nonetheless, the percentage having a part-time job among individual workers in a household is around 10 per cent up to the very top decile of household earnings. Clearly, part-time employment is one of the mechanisms evening out individual earnings inequality over household incomes.

Potentially, it also implies a significant variation in individual earnings levels especially at the top where the role of single-earners is so limited. Obviously, these must be persons who earn a high wage found at the top of the individual earnings distribution. As we have seen, the earnings correlation among dual and multiple earners is far from perfect and we can be certain that these households will also contain persons originating from the lower echelons of individual earnings. Though nothing in principle prevents individual earners in 'more-earner' households from having high earnings (and some certainly will have), the average outcome in practice is that they have lower earnings which combine into high income. In dual-earner households main earners receive almost 40 per cent less than top-decile single earners, with significant variation (20-60 per cent); in multiple-earner households this is more than 50 per cent less (30-70 per cent). ${ }^{14}$ Naturally, the remaining earners in these households have lower earnings.

By way of conclusion from this and the preceding argument, we can say that households' joint labour supply plays an important role, increasingly lifting employee households to the top of the income distribution and largely explaining their important presence among the top 10 per cent. Interestingly, this holds within a relatively narrow band for most EU countries. For some, especially old EU-15, this may be the result of the recent growth in female employment rates starting from low levels in the 1970s, while the other countries were rather familiar with high female employment rates before transition and admission to the European Union.

\subsection{Mutually reinforcing inequalities?}

Combining lower levels of earnings may point to a strategy employed by the household for escaping poverty, standard poverty rates being much lower among dual-earner and multiple-earner households than among single earners. ${ }^{15}$ Conversely, it suggests that households high up the income distribution may gather part of their incomes in lower-paid segments of the labour market. While thus far all attention has been directed at annual

14. Compare Salverda/Haas (2014: fig. 3.11).

15. The average poverty rate is 18 per cent among single earners, 5 per cent among dual earners and 3 per cent among multiple earners. 


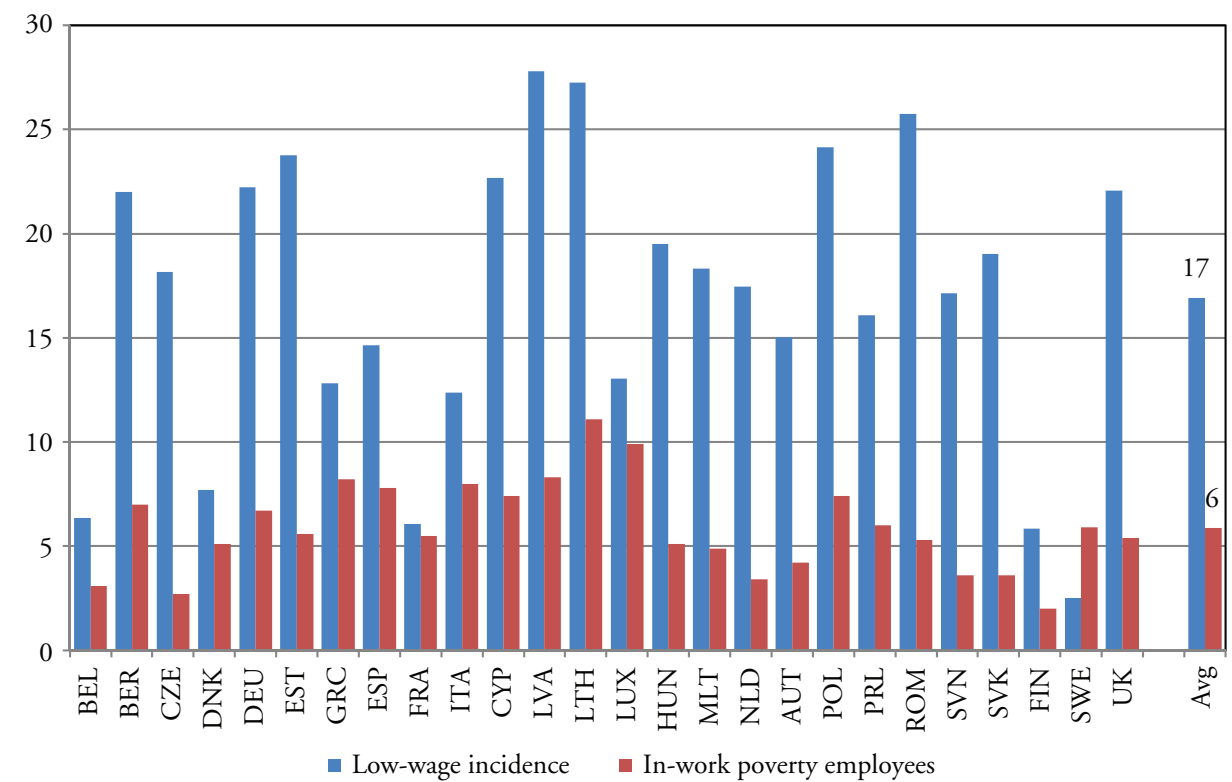

Note: 60 per cent of median equivalised household income cut-off for poverty and 66 per cent of gross median earnings cut-off for low pay.

Source: Calculated from Eurostat, Structure of Earnings Survey [earn_ses_hourly] and At-risk-ofpoverty rate [ilc_li04].

Figure 4 Incidence of low pay and in-work poverty among employees, 2010

earnings - that is, the combination of hours and hourly earnings - we are now particularly interested in low hourly earnings, commonly defined as less than 66 per cent of median hourly earnings. Figure 4 shows that among employees individual low hourly pay is a much more frequent phenomenon than household in-work poverty in all European countries (with the exception of Sweden where the low-pay incidence is remarkably low). Across the countries the low-pay incidence is 17 per cent on average while in-work poverty is 6 per cent. This implies a significant presence of low-paid individuals who live in nonpoor households. Using ECHP data for the year 2000 it can be calculated, for example, that in Germany, Denmark and the Netherlands each of the five upper-half deciles of gross household incomes, including the tenth, holds 11 to 13 per cent of all households comprising a low-wage worker - thus around 60 per cent of all households with a lowpaid worker are found in the upper half of the distribution. ${ }^{16}$

The data also indicate an important role for the combination with part-time work, which grows stronger towards the top of the distribution. The potential role of parttime jobs is corroborated by the correlation of the level of pay with the number of hours worked demonstrated in various Review of Economic Dynamics papers. In other words, part-time jobs are more frequently low paid than full-time jobs. In the case of

16. Unfortunately, hourly pay data are more problematic in SILC than in the preceding ECHP and they are also difficult to match exactly to annual earnings and incomes, which relate to the year preceding the SILC survey. 
the Netherlands, hourly pay clearly declines with the job's number of weekly hours and in total close to 40 per cent of all part-time jobs ( $<35$ hours/week) are low paid, which contrasts with just 11 per cent of full-time jobs. In addition, the incidence of part-time jobs is higher at lower occupational levels, especially for female employment: close to 90 per cent of their elementary and lower-level jobs ${ }^{17}$ are part-time.

This provides evidence that many high-income households may actually comprise individuals who operate in low-wage labour markets, likely in a scenario of combining employment with other activities such as household care or education and training. If the role of high-earnings households (Figure 2) continues to expand, this effect is apt to increase. Plausibly, the labour-market competition of those individuals will be on different terms, as they are primarily interested in part-time hours to ease the combination (work-life balance). In addition, their wage demands may be mitigated by the lower level of (individual) taxation of part-time earnings given taxation's usual focus on annual earnings. Thus the presence of this supply may stimulate employers to increase part-time employment to the disadvantage of full-time jobs and restrain wage levels. As a result, enhanced pressure is put on the (low-skilled) labour supply which is dependent on these markets of low-wage jobs and low occupational levels, as finding full-time jobs becomes increasingly difficult and pay levels remain depressed. It points to a negative feedback mechanism where increasing income inequality, in so far as it mirrors the growing importance of employee households that obtain a high level of income by means of joint labour supply, feeds upon itself by reducing labour market chances for low-skill households.

\section{DISCUSSION}

Employee earnings make an important and steadily increasing contribution to the broad top share (10 per cent) of the household income distribution. Across the EU, 70 per cent of all household incomes and 80 per cent of top-10-per-cent incomes rest on (annual) earnings. This is only partly due to the notorious rise in the pay of individuals at the top of the earnings distribution. It largely rests - at a ratio of almost 9:1 - on the increasing proportion of households with more than one earner, and the concomitant demise of the single-breadwinner model. At the low end of the distribution, the situation is the complete opposite, with close to 90 per cent of households being single earners. As a result only 5 per cent of all employees are in bottom-decile households while 15 per cent are in top-decile households. This complicates the relationship between individual wage inequality on the one hand and household income inequality on the other. In the full-time single-earner world, the two distributions were basically identical, while today combining lower individual and possibly part-time earnings allows households to achieve higher incomes.

This has various important analytical implications. First, it actually mitigates the effects of wage inequality - for the persons involved - as the earnings that are combined in the household do not perfectly correlate: higher and lower earnings combine and even out in household income terms. Second, as earnings are the product of hours worked and hourly pay, the household distribution of hours worked has become an important dimension of income inequality, next to the commonly studied level of pay, and the mitigation of wage inequality resides in both. Pay levels are not perfectly correlated nor are hours worked. Third, this implies that high-income households also supply labour to the low-wage labour market. This enhances competition for (low-skill) low-income households and

17. Dutch occupational levels are defined by the educational skills needed. Compare Salverda (2015). 
affects the distribution of employment chances and hours over households, potentially ousting some of them into joblessness. In this way the combination of earners may reinforce income inequality by its negative effects on labour-market participation of persons and households who thus remain outside the group of employees for whom wage inequality may be mitigated by their household incomes. Fourth, there may be macroeconomic effects given the aggregate importance of the top decile - which comprises 28 per cent of all household incomes across the EU. Evidently, it seems wise to reflect on the rising concentration of employees at the top of the income distribution. The combination of lower earnings levels, on which this partly rests, may affect for example the pattern of highincome spending or their taxation (in countries with individual taxation). ${ }^{18}$

Finally, the more complex relationship between wage and income inequalities is important to consider also for its policy implications. The death of the single-breadwinner model has also reduced the opportunities for the labour market to take (some) care for the household via (minimum) earnings. The potential repercussion of household earnings inequality on the low-wage labour market - as high-income households may operate in that segment to the disadvantage of low-skilled labour supply seeking full-time employment for the purpose of subsistence - may be here to stay. This puts doubt on the common approach that seeks the solution to the low employment rates and high joblessness rates among the lowskill population exclusively in the improvement of their education and training or the lowering of levels of pay. The presence of low-paid individuals in high-income households blunts the efficacy of traditional instruments, such as the minimum wage or working tax credits, for income redistribution via individual pay. Certainly, they can still help to relieve poverty but at much increased deadweight costs. It also complicates redistributive measures in a more fundamental, politico-social way in countries with individual income taxation systems that disregard household outcomes, if households manage to achieve high incomes with the help of combining mediocre or even low levels of individual pay. Imaginably, it will be difficult for the persons involved to support increased taxation aimed at redistribution towards other individuals who receive comparable pay but are members of a household that is unable, or perhaps even unwilling, to supply another worker. The way back from individual- to household-based taxation seems as undesirable for reasons of principle as it is unfeasible politically because of the massive all-permeating nature of the labour-market changes. An improved targeting of the needy households on the benefit side of the redistributive equation seems a better solution. Instead of considering an Earned Income Tax Credit a second-best solution, suitable or inevitable perhaps for a deficient welfare state only, it may actually be refurbished as an instrument that can help solve an essential problem of income solidarity generated by the rise of the dual-earner model with which Europe has been rapidly following the American example.

18. In the Netherlands the effective average income-tax rate of dual-earner fiscal units at the top is much lower for both the main earner (22 per cent) and their partner (12 per cent) in comparison to single earners ( 27 per cent), in spite of a slightly higher combined income. Evidently, the increasing role of those units may limit the growth of tax receipts. 


\section{REFERENCES}

Aaberge, R., Melby, I. (1998): The sensitivity of income inequality to choice of equivalence scales, in: Review of Income and Wealth, 44(4), 565-569.

Alvaredo, F. (2011): A note on the relationship between top income shares and the Gini coefficient, in: Economics Letters, 110(3), 274-277.

Atkinson, A.B., Brandolini, A. (2006): From earnings dispersion to income inequality, in: Farina, F., Savaglia, E. (eds), Inequality and Economic Integration, London: Routledge, 35-62.

Atkinson, A.B., Piketty, T. (eds) (2007): Top Incomes over the Twentieth Century: A Contrast Between Continental European and English-Speaking Countries, Oxford: Oxford University Press.

Blundell, R., Etheridge, B. (2010): Consumption, income and earnings inequality in Britain, in: Review of Economic Dynamics, 13(1), 76-102.

Brewer, M., Wren-Lewis, L. (2012): Why did Britain's households get richer? Decomposing UK household income growth between 1968 and 2008-09, Working Paper 2012-08, ISER, University of Essex.

Brzozowski, M., Gervais, M., Klein, P., Suzuki, M. (2010): Consumption, income, and wealth inequality in Canada, in: Review of Economic Dynamics, 13(1), 52-75.

Domeij, D., Floden, M. (2010): Inequality trends in Sweden 1978-2004, in: Review of Economic Dynamics, 13(1), 179-208.

Freeman, R. (2006): The Great Doubling: The Challenge of the New Global Labor Market, URL: http://emlab.berkeley.edu/users/webfac/eichengreen/e183_sp07/great_doub.pdf.

Fuchs-Schündeln, N., Krueger, D., Sommer, M. (2010): Inequality trends for Germany in the last two decades: a tale of two countries, in: Review of Economic Dynamics, 13(1), 103-132.

Gottschalk, P., Danziger, S. (2005): Inequality of wage rates, earnings and family income in the United States 1975-2002, in: Review of Income and Wealth, 51(2), 231-254.

Heathcote, J., Perri, F., Violante, G. (2010): Unequal we stand: an empirical analysis of economic inequality, in: Review of Economic Dynamics, 13, 15-51.

Japelli, T., Pistaferri, L. (2010): Does consumption inequality track income inequality in Italy?, in: Review of Economic Dynamics, 13(1), 133-153.

Kenworthy, L. (2008): Sources of equality and inequality: wages, jobs, households, and redistribution, Working Paper 471, Luxembourg Income Study. (First published in Kenworthy, L. (2008): Jobs with Equality, Oxford: Oxford University Press, 30-53.)

Leigh, A. (2007): How closely do top income shares track other measures of inequality?, in: Economic Journal, 117(524), F619-F633.

Maestri, V., Bogliacino, F., Salverda, W. (2014): Wealth inequality and the accumulation of debt, in: Salverda, W., Nolan, B., Checchi, D., Marx, I., McKnight, A., György Tóth, I., van de Werfhorst, H. (eds) (2014): Changing Inequalities in Rich Countries: Analytical and Comparative Perspectives, Oxford: Oxford University Press, 82-120.

OECD (2008): Growing Unequal? Income Distribution and Poverty in OECD Countries, Paris: OECD Publishing.

OECD (2011): Divided We Stand: Why Inequality Keeps Rising, Paris: OECD Publishing.

Peichl, A., Pestel, N., Schneider, H. (2010): Does size matter? The impact of changes in household structure on income distribution in Germany, CESifo Working Paper 3219.

Pen, J., Tinbergen, J. (1976): Hoeveel bedraagt de inkomensegalisatie sinds 1938?, in: EconomischStatistische Berichten, 61(3070), 880-884.

Pijoan-Mas, J., Sánchez-Marcos, V. (2010): Spain is different: falling trends of inequality, in: Review of Economic Dynamics, 13(1), 154-178.

Piketty, T. (2014): Capital in the Twenty-first Century, Cambridge, MA: Harvard University Press.

Piketty, T., Saez, E. (2003): Income inequality in the United States, 1913-1998, in: Quarterly Journal of Economics, 118(1), 1-39.

Salverda, W. (2014): De tektoniek van de inkomensongelijkheid in Nederland [Tectonics of Income Inequality in the Netherlands], in: Kremer, M., Bovens, M., Schrijvers, E., Went, R. (eds), Geld en (on)gelijkheid, Amsterdam: WRR (Scientific Council for Government Policy)/Amsterdam University Press, 39-58. 
Salverda, W. (2015): Merit en werk in 1960-2010: effecten van de Nederlandse onderwijs- en deeltijdtsunami's [Merit and work 1960-2010: effects of the tsunamis of educational attainment and part-time work in the Netherlands], in: Van de Werfhorst, H.G. (ed.), Een kloof van alle tijden: Verschillen tussen lager en hoger opgeleiden in werk, cultuur en politiek, Amsterdam: Amsterdam University Press (in press).

Salverda, W., Atkinson, A.B. (2007): Top incomes in the Netherlands over the twentieth century, in: Atkinson, A.B., Piketty, T. (eds), Top Incomes over the Twentieth Century: A Contrast Between Continental European and English-Speaking Countries, Oxford: Oxford University Press, 426-471.

Salverda, W., Checchi, D. (2014): Labour-market institutions and the dispersion of wage earnings, in: Atkinson, A.B., Bourguignon, F. (eds), Handbook of Income Distribution, Volume 2B, Amsterdam: Elsevier/North Holland, 1535-1727, URL: http://ftp.iza.org/dp8220.pdf.

Salverda, W., Haas, C. (2014): Earnings, employment and income inequality, in: Salverda, W., Nolan, B., Checchi, D., Marx, I., McKnight, A., György Tóth, I., van de Werfhorst, H. (eds) (2014): Changing Inequalities in Rich Countries: Analytical and Comparative Perspectives, Oxford: Oxford University Press, 48-81.

Salverda, W., Nolan, B., Checchi, D., Marx, I., McKnight, A., György Tóth, I., van de Werfhorst, H. (eds) (2014): Changing Inequalities in Rich Countries: Analytical and Comparative Perspectives, Oxford: Oxford University Press.

Večerník, J. (2010): Earnings disparities and income inequality in CEE countries: an analysis of development and relationships, Working Paper 540, Luxembourg Income Study. 